medRxiv preprint doi: https://doi.org/10.1101/2021.03.25.21254356; this version posted March 26, 2021. The copyright holder for this preprint (which was not certified by peer review) is the author/funder, who has granted medRxiv a license to display the preprint in perpetuity.

It is made available under a CC-BY-NC 4.0 International license .

\title{
Molecular beacons allow specific RT-LAMP detection of B.1.1.7 variant SARS-CoV-2
}

\author{
Scott Sherrill-Mix ${ }^{1,2}$, Gregory D. Van Duyne ${ }^{3}$ and Frederic D. Bushman ${ }^{1}$ \\ 1 Department of Microbiology, Perelman School of Medicine, University of \\ Pennsylvania, Philadelphia, PA 19104 \\ 2 Department of Medicine, Perelman School of Medicine, University of Pennsylvania, \\ Philadelphia, PA 19104 \\ 3 Department of Biochemistry and Biophysics, Perelman School of Medicine, \\ University of Pennsylvania, Philadelphia, PA 19104
}

Keywords: RT-LAMP, molecular beacon, SARS-CoV-2, detection, variant, B.1.1.7 


\begin{abstract}
Over the course of the COVID-19 pandemic, several SARS-CoV-2 genetic variants of concern have appeared and spread throughout the world. Detection and identification of these variants is important to understanding and controlling their rapid spread. Current detection methods for a particularly concerning variant, B.1.1.7, require expensive qPCR machines and depend on the absence of a signal rather than a positive indicator of variant presence. Here we report an assay using a pair of molecular beacons paired with reverse transcription loop mediated amplification to allow isothermal amplification from saliva to specifically detect B.1.1.7 and other variants which contain a characteristic deletion in the gene encoding the viral spike protein. This assay is specific, affordable and allows multiplexing with other SARS-CoV-2 LAMP primer sets.
\end{abstract}

\title{
Introduction
}

SARS-CoV-2 virus was first detected in December of 2020 and rapidly spread throughout the world. To date, the virus has infected over 120 million people and caused over 2.5 million deaths. Over the course of the pandemic, several genetic variants of concern have appeared and rapidly increased in frequency. The effects of these mutations remain unclear but there is concern that these variants may alter virus phenotype, affect detection and escape immune responses ${ }^{1-10}$.

Several variants of concern, including the B.1.1.7 variant first identified in the UK, have a characteristic six nucleotide deletion in the spike gene (S1 $\Delta 69-70)$ that appears likely to be an effective target for detection by nucleic acid testing. Detection of these variants currently requires observation of the dropout of fluorescence from a spike-targeted primer-probe set during $\mathrm{qPCR}^{1}$. However, screening using the absence of a signal is prone to falsely label samples near the limit of detection or assay failures as variants and performing qPCR requires costly RT-qPCR machines. Here, we design a molecular beacon spanning this S1 $\Delta 69-70$ deletion that allows characterization of virus using simple isothermal reverse transcription-loop mediated amplification (RT-LAMP).

\section{Materials and Methods}

To initiate LAMP reactions, primers are designed such that the ends of the synthesized DNA will form two dumbbell-like loops of single stranded DNA. The single stranded sequence in these loops is dependent on the template DNA and can be completely independent of the primers input to the reaction. Thus this sequence is resistant to creation by artifactual off-target amplification and available for annealing, making it a favorable target for molecular beacons. We used the Primer Explorer software to design a LAMP primer set (S6970) spanning the S1 $\Delta 69-70$ deletion such that the deletion falls within the backward loop region of the amplification (Table 1) and then designed a molecular beacon (S6970_B117_MB) to both land inside the loop and span the deletion. We also added locked nucleic acids to increase specificity and strengthen hybridization to allow real time detection at the temperatures used in LAMP. In addition, we synthesized an additional molecular beacon (S6970_WT_MB) targeting the undeleted S1 69-70 sequence to allow parallel detection of strains containing the preexisting spike sequence (Figure 1A).

We then tested the S6970 primers and beacons on synthetic RNA from wild-type (Twist Australia/VIC01/2020) and B.1.1.7 (Twist England/205041766/2020) SARS-CoV-2 variants. For comparison, we also multiplexed S6970 with the N2 primer set ${ }^{11}$ and molecular beacon ${ }^{12}$. For these experiments, S6970_B117_MB was synthesized with a fluorescein (Fam) label, S6970_WT_MB with a cyanine 3 (Cy3) label and N2_MB with a cyanine (Cy5) label.

Reactions were performed using locally produced enzyme mix equivalent to commercial RT-LAMP $\operatorname{mix}^{12}$. Reactions consisted of $10 \mu \mathrm{L}$ of $2 \mathrm{x}$ RT-LAMP enzyme mix, $2 \mu \mathrm{L}$ of $10 \mathrm{x}$ primer-beacon mix and $8 \mu \mathrm{L}$ of water doped with varying amounts of synthetic RNA. 10x primer-beacon mix consisted of $16 \mu \mathrm{M} \mathrm{FIP,} 16 \mu \mathrm{M}$ BIP, 
$4 \mu \mathrm{M}$ LF, $4 \mu \mathrm{M}$ LB, $2 \mu \mathrm{M}$ B3, $2 \mu \mathrm{M}$ F3, $2.5 \mu \mathrm{M}$ S6970_WT_MB beacon and 2.5 M S6970_B117_MB beacon. For multiplexed S6970 and N2 primer-beacon mix, the primer concentrations were halved and beacon N2_MB was added while maintaining all beacon concentrations at $2.5 \mu \mathrm{M}$.

Reactions were incubated for 60 minutes at $63^{\circ} \mathrm{C}$ using a QuantStudio $5 \mathrm{qPCR}$ machine for real-time quantification or a simple heat block. Note that the long incubation time was used to verify that no false positives were observed and most reactions completed within 30 minutes. We also used a simple and affordable $(\sim 25)$ illuminator (miniPCR p51) using blue light emitting diodes and an orange filter to observe the endpoint fluorescence of these assays.

\section{Results}

Our goal was to design two molecular beacons that could be combined in a single reaction to distinguish SARS-CoV-2 variants containing the S1 $\Delta 69-70$ deletion. To test our design, we used synthetic SARS-CoV-2 RNA containing either a prototypical genome sequence from early in the pandemic or a genome containing S1 $\Delta 69-70$ deletion. We saw that fluorescence of two molecular beacons, S6970_WT_MB and S6970_B117_MB, was easily visible by eye or cell phone camera after isothermal RT-LAMP and that the distinction between yellow Cy3 and green Fam allowed visual characterization of SARS-CoV-2 variants (Figure 1B).

To characterize the sensitivity and replicability of this assay, we attempted to amplify across a range of 10,000 to 39 genome copies per reaction (Figure 2A). The S6970 beacons were specific to their intended target with only minimal fluorescence detected from S6970_WT_MB when Twist B.1.1.17 was amplified and only minimal fluorescence detected from S6970_B117_MB when wild type Twist was amplified. In contrast, in the presence of their intended targets, the beacons were strongly fluorescent. For comparison, the S6970 primer set was also multiplexed with the sensitive N2 primer set and molecular beacon. The N2 beacon was highly fluorescent for all positive samples (Figure 2B). In contrast, the S6970 primer set was less sensitive only detecting 11/12 reactions containing 625 genomic copies, 10/12 containing 312 copies, 9/12 containing 156 copies, 6/12 containing 78 copies and 5/12 containing 39 copies. No false positives were observed in any beacon.

Estimating the probability of detecting a single copy of target RNA as $p$ (positive|copies, detectionRate) $=$ $1-(1-\text { detectionRate })^{\text {copies }}$, the maximum likelihood estimate for the detection of a single copy for S6970 was $0.7 \%$ and the copy number necessary to give a $95 \%$ detection rate was estimated at 430 copies. With 8 $\mu \mathrm{L}$ of saliva input to each reaction, this translates to a detection at 54 copies per $\mu \mathrm{L}$ of saliva. This is less sensitive than the best SARS-CoV-2 primer sets, for example the N2 primer set used here, so would not be optimal for use as the only primer set in first line screening. But the primer set would be well suited to a follow up test of potential positives or multiplexed with more sensitive primer sets (Figure 2B). Due to the dual beacon design, the S6970 assay gives a clear readout of either WT SARS-CoV-2 detection or S1 $\Delta 69-70$ detection or failure to detect either. Failures to detect SARS-CoV-2 in samples that are believed to be positive can be followed up with larger or more numerous reactions to give a higher probability of detection.

\section{Discussion}

Here we show that molecular beacons and LAMP provide an effective method for detecting SARS-CoV-2 variants containing the S1 $\Delta 69-70$ deletion. Using simple isothermal amplification of unpurified saliva and endpoint fluorescence, the genotype of a viral sample can be determined visually without expensive equipment. With locally-purified enzymes ${ }^{12}$, the reagents costs can be reduced to pennies per test. Combined with the easily parallelizable nature of isothermal incubation, scaling is effectively limited only by sample collection and processing. Although the large deletion found in this variant was particularly well suited for detection, molecular beacons are often used to detect even single nucleotide polymorphisms ${ }^{13}$. This pilot study showcases the capabilities of RT-LAMP and molecular beacons and promises further improvements in the monitoring 
medRxiv preprint doi: https://doi.org/10.1101/2021.03.25.21254356; this version posted March 26, 2021. The copyright holder for this preprint (which was not certified by peer review) is the author/funder, who has granted medRxiv a license to display the preprint in perpetuity.

It is made available under a CC-BY-NC 4.0 International license .

and control of variants of concern through the design of additional beacons targeting diagnostic genetic signatures.

\section{Acknowledgements}

This work was funded by the Penn Center for Research on Coronaviruses and Other Emerging Pathogens. We thank Young Hwang, Aoife Roche and members of the COVID-SAFE laboratory for help and suggestions. 


\section{References}

[1] A Bal, G Destras, A Gaymard, K Stefic, J Marlet, S Eymieux, H Regue, Q Semanas, C d'Aubarede, G Billaud, F Laurent, C Gonzalez, Y Mekki, M Valette, M Bouscambert, C Gaudy-Graffin, B Lina, F Morfin and LJ and. 2021. Two-step strategy for the identification of SARS-CoV-2 variant of concern 202012/01 and other variants with spike deletion H69-V70, France, August to December 2020. Eurosurveillance, 26. doi: 10.2807/1560-7917.es.2021.26.3.2100008

[2] DP Martin, S Weaver, H Tegally, EJ San, SD Shank, E Wilkinson, J Giandhari, S Naidoo, Y Pillay, L Singh, RJ Lessells, RK Gupta, JO Wertheim, A Nekturenko, B Murrell, GW Harkins, P Lemey, OA MacLean, DL Robertson et al. 2021. The emergence and ongoing convergent evolution of the N501Y lineages coincides with a major global shift in the SARS-CoV-2 selective landscape. medRxiv. doi: $10.1101 / 2021.02 .23 .21252268$

[3] TN Starr, AJ Greaney, SK Hilton, D Ellis, KH Crawford, AS Dingens, MJ Navarro, JE Bowen, MA Tortorici, AC Walls, NP King, D Veesler and JD Bloom. 2020. Deep mutational scanning of SARS-CoV-2 receptor binding domain reveals constraints on folding and ACE2 binding. Cell, 182: 1295-1310.e20. doi: 10.1016/j.cell.2020.08.012

[4] SA Kemp, B Meng, IA Ferriera, R Datir, WT Harvey, G Papa, S Lytras, DA Collier, A Mohamed, G Gallo, N Thakur, AM Carabelli, JC Kenyon, AM Lever, AD Marco, C Saliba, K Culap, E Cameroni, L Piccoli et al. 2020. Recurrent emergence and transmission of a SARS-CoV-2 spike deletion H69/V70. bioRxiv. doi: 10.1101/2020.12.14.422555

[5] SA Kemp, DA Collier, RP Datir, IATM Ferreira, S Gayed, A Jahun, M Hosmillo, C Rees-Spear, P Mlcochova, IU Lumb, DJ Roberts, A Chandra, N Temperton, K Sharrocks, E Blane, Y Modis, KE Leigh, JAG Briggs, MJ van Gils et al. 2021. SARS-CoV-2 evolution during treatment of chronic infection. Nature. doi: 10.1038/s41586-021-03291-y

[6] DA Collier, AD Marco, IA Ferreira, B Meng, R Datir, AC Walls, SAK S, J Bassi, D Pinto, CS Fregni, S Bianchi, MA Tortorici, J Bowen, K Culap, S Jaconi, E Cameroni, G Snell, MS Pizzuto, AF Pellanda et al. 2021. Sensitivity of SARS-CoV-2 B.1.1.7 to mRNA vaccine-elicited antibodies. Nature. doi: $10.1038 / \mathrm{s} 41586-021-03412-7$

[7] A Muik, AK Wallisch, B Sänger, KA Swanson, J Mühl, W Chen, H Cai, D Maurus, R Sarkar, Özlem Türeci, PR Dormitzer and U Şahin. 2021. Neutralization of SARS-CoV-2 lineage B.1.1.7 pseudovirus by BNT162b2 vaccine-elicited human sera. Science, 371:1152-1153. doi: 10.1126/science.abg6105

[8] K Wu, AP Werner, JI Moliva, M Koch, A Choi, GBE Stewart-Jones, H Bennett, S Boyoglu-Barnum, W Shi, BS Graham, A Carfi, KS Corbett, RA Seder and DK Edwards. 2021. mRNA-1273 vaccine induces neutralizing antibodies against spike mutants from global SARS-CoV-2 variants. bioRxiv. doi: $10.1101 / 2021.01 .25 .427948$

[9] AJ Greaney, AN Loes, KH Crawford, TN Starr, KD Malone, HY Chu and JD Bloom. 2021. Comprehensive mapping of mutations in the SARS-CoV-2 receptor-binding domain that affect recognition by polyclonal human plasma antibodies. Cell Host Microbe, 29:463-476.e6. doi: 10.1016/j.chom.2021.02.003

[10] NG Davies, S Abbott, RC Barnard, CI Jarvis, AJ Kucharski, JD Munday, CAB Pearson, TW Russell, DC Tully, AD Washburne, T Wenseleers, A Gimma, W Waites, KLM Wong, K van Zandvoort, JD Silverman, K Diaz-Ordaz, R Keogh, RM Eggo et al. 2020. Estimated transmissibility and impact of SARS-CoV-2 lineage B.1.1.7 in England. medRxiv. doi: 10.1101/2020.12.24.20248822

[11] Y Zhang, G Ren, J Buss, AJ Barry, GC Patton and NA Tanner. 2020. Enhancing colorimetric loopmediated isothermal amplification speed and sensitivity with guanidine chloride. BioTechniques, 69: 178-185. doi: 10.2144/btn-2020-0078

[12] S Sherrill-Mix, Y Hwang, AM Roche, SR Weiss, Y Li, J Graham-Wooten, LJ Taylor, RG Collman, GD Van Duyne and FD Bushman. 2020. LAMP-BEAC: detection of SARS-CoV-2 RNA using RT-LAMP and molecular beacons. medRxiv. doi: 10.1101/2020.08.13.20173757 
medRxiv preprint doi: https://doi.org/10.1101/2021.03.25.21254356; this version posted March 26, 2021. The copyright holder for this preprint (which was not certified by peer review) is the author/funder, who has granted medRxiv a license to display the preprint in perpetuity. It is made available under a CC-BY-NC 4.0 International license .

[13] M Varona and JL Anderson. 2019. Visual detection of single-nucleotide polymorphisms using molecular beacon loop-mediated isothermal amplification with centrifuge-free DNA extraction. Anal Chem, 91: 6991-6995. doi: 10.1021/acs.analchem.9b01762 
medRxiv preprint doi: https://doi.org/10.1101/2021.03.25.21254356; this version posted March 26, 2021. The copyright holder for this preprint (which was not certified by peer review) is the author/funder, who has granted medRxiv a license to display the preprint in perpetuity.

It is made available under a CC-BY-NC 4.0 International license .

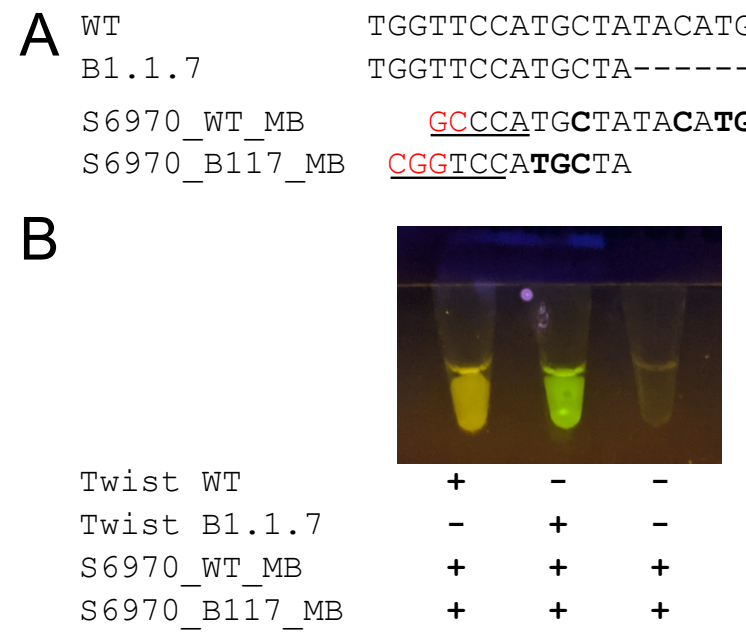

Figure 1: Development of molecular beacons to discriminate SARS-CoV-2 variants with a S1 $\Delta 69-70$ mutation. A) A comparison of preexisting genomic S1 sequence (WT) and variant B.1.1.7 genomic sequence (B.1.1.7) and molecular beacons targeting these sequences (S6970_WT_MB and S6970_B117_MB, respectively). Dashes indicate the S1 $\Delta 69-70$ deletion, bold letters indicate locked nucleic acids, underlined letters indicate bases paired in the stem of the beacon and red letters indicate extra nucleotides added to form the stem. B) Demonstration of visual detection using the molecular beacons. LAMP reactions with molecular beacons at a final concentration of $0.25 \mu \mathrm{M}$ were incubated using a heat block and the endpoint fluorescence was visualized using a low cost viewer (miniPCR p51) and cell phone camera (Google Pixel 2 "Night Sight" mode). 

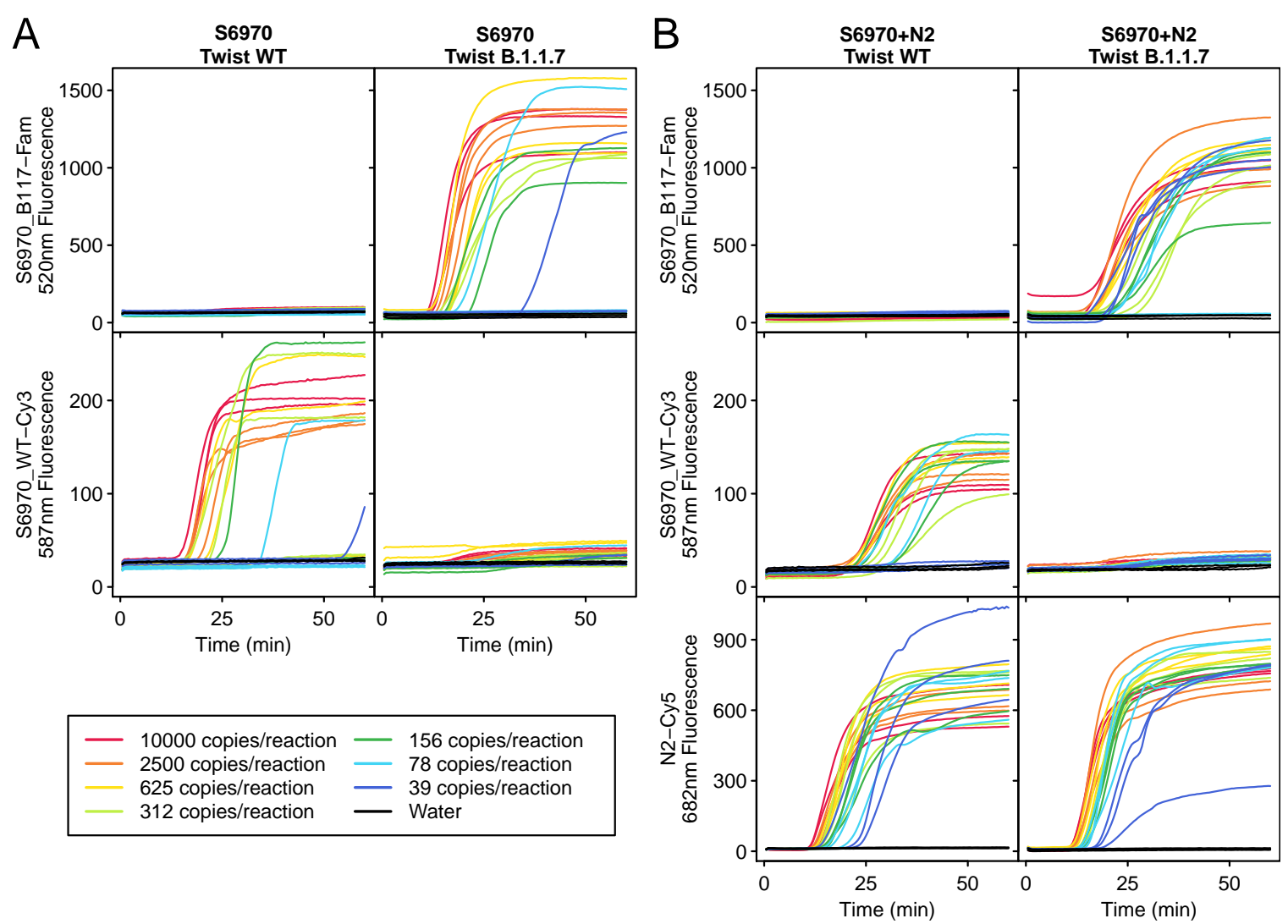

Figure 2: Testing of the S6970 primer set and molecular beacons on synthetic SARS-CoV-2 RNA. Fluorescence was monitored over time for LAMP isothermal amplification using the S6970 primer set alone or S6970 multiplexed with N2 primer for Twist Australia/VIC01/2020 (Twist WT) and Twist England/205041766/2020 (Twist B.1.1.7). The amount of synthetic SARS-CoV-2 RNA in each reaction was varied from 10,000 to 39 copies (indicated by line color) or water control (black). All fluorescence is given as relative fluorescence units (RFU) divided by 1000 . 
medRxiv preprint doi: https://doi.org/10.1101/2021.03.25.21254356; this version posted March 26, 2021. The copyright holder for this preprint (which was not certified by peer review) is the author/funder, who has granted medRxiv a license to display the preprint in perpetuity.

It is made available under a CC-BY-NC 4.0 International license .

Table 1: Oligonucleotides used in this study.

\begin{tabular}{|c|c|}
\hline Name & Sequence $^{\dagger}$ \\
\hline S6970_F3 & TGTGTTAATCTTACAACCAGAA \\
\hline S6970_B3 & GGAAGCAAAATAAACACCATCA \\
\hline S6970_FIP & AACTGAGGATCTGAAAACTTTGTCA-TCAATTACCCCCTGCATAC \\
\hline S6970_BIP & TTACATTCAACTCAGGACTTGTTCT-TTATCAAACCTCTTAGTACCATTG \\
\hline S6970_LF & GGGTAATAAACACCACGTGTGA \\
\hline S6970_LB & TTTCCAATGTTACTTGGTTCCATGC \\
\hline S6970_B117_MB & Fam-CGGTCCA+T+G+CTA+T+CT+CTGGGACCG-IBFQ \\
\hline S6970_WT_MB & Cy3-GCCCATG+CTATA+CA+T+GT+CT+CTGGGC-IBRQ \\
\hline $\mathrm{N} 2 \_\mathrm{F} 3^{\ddagger}$ & ACCAGGAACTAATCAGACAAG \\
\hline N2_B3 ${ }^{\ddagger}$ & GACTTGATCTTTGAAATTTGGATCT \\
\hline N2_FIP $\ddagger$ & TTCCGAAGAACGCTGAAGCGGAACTGATTACAAACATTGGCC \\
\hline N2_BIP $\ddagger$ & CGCATTGGCATGGAAGTCACAATTTGATGGCACCTGTGTA \\
\hline $\mathrm{N} 2 \_\mathrm{LF}^{\ddagger}$ & GGGGGCAAATTGTGCAATTTG \\
\hline $\mathrm{N} 2 \_\mathrm{LB} \_2^{\ddagger}$ & GGAACGTGGT+T+GACC \\
\hline $\mathrm{N} 2 \_\mathrm{MB}^{\ddagger}$ & $\mathrm{Cy} 5-\mathrm{CCAC}+\mathrm{CTTCG}+\mathrm{G}+\mathrm{GAA}+\mathrm{CG}+\mathrm{T}+\mathrm{GGTGG}-\mathrm{IBRQ}$ \\
\hline
\end{tabular}

${ }^{\dagger}$ Shown in $5^{\prime}$ to $3^{\prime}$ orientation. $+\mathrm{X}$ indicates a locked nucleic acid. IBFQ indicates Iowa Black FQ and IBRQ indicates Iowa Black RQ dark quenchers.

${ }^{\ddagger}$ N2_LB_2 and N2_MB are from Sherrill-Mix et al. ${ }^{12}$ Other N2 primers are from Zhang et al. ${ }^{11}$ 